\title{
Agricultural Cultivation Land on Landslides Deposit, Bogowonto Catchment, Central Java, Indonesia
}

\section{Nur Ainun Harlin Jennie Pulungan*}

Soil Department, Agriculture Faculty, Universitas Gadjah Mada, Yogyakarta, Indonesia

*Corresponding Author: Nur Ainun Harlin Jennie Pulungan, Soil Department, Agriculture Faculty, Universitas Gadjah Mada, Yogyakarta, Indonesia.
Received: June 21, 2021

Published: August 24, 2021

(C) All rights are reserved by Nur Ainun

Harlin Jennie Pulungan.

\section{Abstract}

The need for agricultural cultivation land is increasing significantly nowadays. However, land expansion which is not accompanied by integrated land management and good development plans can lead to land degradation. As a result, many landslides occur especially in hilly areas. Due to limited of land, landslide deposit areas have a tendency to be used as an alternative for agricultural cultivation land. This research was aimed at investigating the landslide deposit as an alternative agricultural cultivation land. Bogowonto catchment was chosen as the study area. It is an area that has a high level of landslides susceptibility. The Bogowonto has unique physical environmental conditions in terms of soil and soil parent material. Soil units in the Bogowonto catchment have a thickness of more than $2 \mathrm{~m}$ even though they are found on parts of the slope that are sloping to steep. The combination of sloping slopes, high rainfall intensity, and very thick soil cause the study area to be prone to landslides.

The research method used in this study was a survey method. Landslide deposit investigation and soil data collection were carried out on several parts of the slopes of the Bogowonto catchment, which have varied landscape characteristics. The technique of collecting soil sample data was purposive sampling. 8 landslides were chosen as the representatives area to collect soil samples of landslide deposit. The soil samples were collected at depth of 0-20 cm. Data processing was carried out by spatial analysis. Soil analysis was conducted qualitatively in the field and quantitatively in the laboratory.

The results showed that landslides deposit area can be proposed as an alternative to fulfil the need for agricultural cultivation land. Based on land management assessment, the best options for land utilization in landslide deposited area were landslide deposition that contains mainly of soil such as soil derived from volcanic ash, can be cultivated with seasonal crops like cassava, long beans, turmeric, ginger, and sweet potato. Landslide deposition with mixed material (soil and saprolite) can be cultivated with annual crops/ wood crops such as sengon, teak wood, and acacia.

Keywords: Agricultural Cultivation Land; Landslides; Land Management; Hilly Area

\section{Background}

Currently, the need for agricultural cultivation land is increasing. To fulfil this need, most of agricultural cultivation land has expanded to marginal area. Many studies has being discussing about this matter i.e. $[13,15,19,21,22]$. In other side, there are also many threats and dynamics that would be faced in this agricultural cultivation land [34]. [29] revealed that agricultural landscapes cultivated in hilly region are susceptible to soil loss and mass movement. 
The complex morphology that characterizes this region causes this region susceptible to severe slope instability. This is also inline with the study of [27] stated that soil erosion is the main problem in hilly areas. Another fact is also shown by the study of [36] proved that agricultural in hilly area is very sensitive to nutrient loss. However, the need for agricultural cultivation land should be fulfilled. The alternative for land use may become the best options of land management with considering and attempting of adoption the existing condition of the areas.

Landslides deposit area becomes one of alternative to fulfil the need for agricultural cultivation land. Landslide deposit area has a probability to be reused as an agricultural cultivation land since Bogowonto catchment area has high level of landslide susceptibility. Many areas surrounding Bogowonto catchment are suffered by landslides, which have been proved by many researches in that particular area, i.e. $[2,14,20,23,24]$. Therefore, there are many landslide deposit areas that can be used as an alternative to develop agricultural cultivation. This option arises because most people depend on their main income from farming activities.

Integrated land management and development is urgently needed at this time. Land management is assigned as one of the most important questions of agricultural production [17]. This is considering the increasing need for agricultural land which must be accompanied by good and balanced concept of land use planning. The aims of planning of land use are efficiency, equity, acceptability, and sustainability [32]. The management and development of agricultural land requires basic needs in the form of data and maps that can support the strategic planning.

Understanding of physical properties of the soil is the initial stage to know the characteristic of particular agricultural land. An example of the benefit of land management to soil condition was shown in the study of proved that maintenance of $50-70 \%$ ground cover shown to be effective to reduce soil erosion, and contributing to increasing soil carbon content [8]. Adoption of appropriate land use planning based on soil resource information with scientific management practices for crops are a significant alternative for enhancing farmers' income [25].

The Bogowonto Catchment Area is part of Magelang, Purworejo, and Wonosobo Regencies which is geomorphologically located in the Kulonprogo Mountain range. In general, the Bogo- wonto catchment has wavy to mountainous topography. This topographic condition is very prone to cause the process of transporting surface material such as erosion and landslides intensively (i.e. $[13,14,20,23])$. The occurrence of erosion and landslides that dominates in this area becomes an obstacle in the development of agricultural cultivation land.

Appropriate land use management is the core of the study in development of agricultural cultivation land. For this reason, it is necessary to conduct an integrated study between land management and soil characteristics which is also useful for maintaining agricultural cultivation land in these study area. The aim of this research is investigating the landslide deposit as an alternative agricultural cultivation land.

\section{Methods}

Middle part of the Bogowonto catchment area (Figure 1) was chosen as the study area because this area has a high susceptibility of landslides. This condition is caused as a result of simultaneously geological processes that resulted in various soil genesis and relief. The dominant soil parent materials in the study area such as volcanic ash materials, intensive weathering of the parent rocks, and altered parent rocks. In simply, those various soil parent material caused a variation of landslide deposit characteristics.

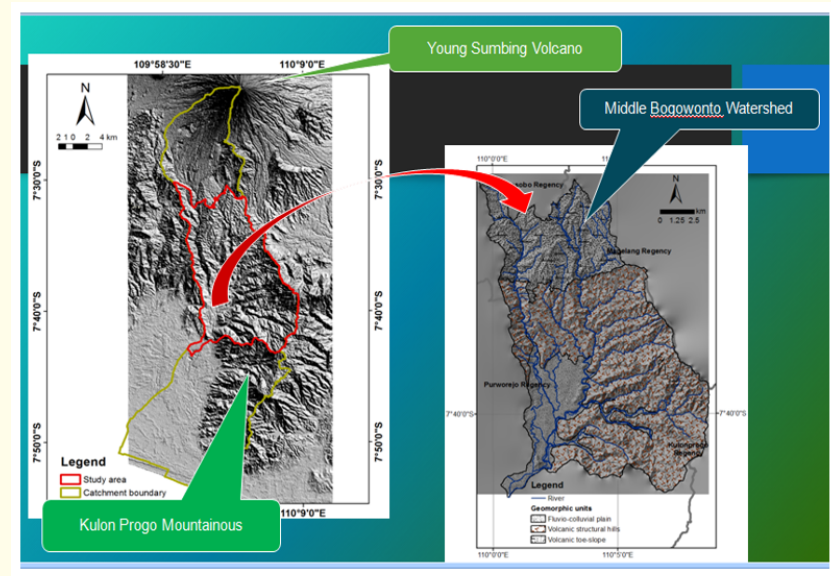

Figure 1: Study area.

Tools and materials used in this research include aerial photography, soil samples, and mapping software. Aerial photography 
was used to make tentative maps and to analyze geomorphic processes. Soil samples as the main material for investigation of soil characteristics in the study area. ArcGIS 10.7 software was used for processing and presenting research data.

The research method used in this study was a survey method. Field survey was conducted for soil data collection and landslides investigation. The technique of collecting soil sample data was purposive sampling based on landscape variation in the study area. There were 8 landslides chosen as the representatives to landslide deposit characteristics of the study area. The soil samples were collected at depth of $0-20 \mathrm{~cm}$.

Data processing was carried out by spatial analysis to process regional morphological interpretation. Soil analysis was conducted qualitatively in the field and quantitatively in the laboratory. Qualitatively, soil profile development was directly described using infield morphological differentiation. Meanwhile, quantitative soil profile development was analyzed in laboratory. Laboratory tests of physical and chemical properties of soil were conducted only for several properties which are essential for plant growth such as: texture, bulk density, bulk volume, porosity, permeability, water content, soil consistence (liquid limit, sticky lmit, plastic limit, tillage limit, and index plasticity), organic carbon, and CEC. The textures were analyzed using pipette method. The soil consistence was analyzed by casagrande method. The organic carbon (C) was measured using wet method by Walkley and Black (1934). The CEC analysis of $\mathrm{NH}_{4} \mathrm{OAc}$ was made at $\mathrm{pH} 7.0$ and followed by distillation of soil-filtered sample.

\section{Results and Discussion}

The morphological characteristics of landslide deposit were the initial appearance that may describe whether the deposit is able to be cultivated or not. Based on field assessments, they showed that soil structure in landslide deposit was mostly dominated by crumb to small blocky under weak to moderate grade. The results also showed that the landslide deposit has mainly friable for moist soil consistency and slight sticky to sticky as well as slightly plastic to no plastic for wet soil consistency. Also, the surface roughness of the deposit is dominantly rough since the movement of soil material in the landslide body has mixed the materials.

Particle size distribution is an important soil property that can describe the impact of landslide on redistributing the soils. The dis- tribution of particle size of landslide deposit showed a dominant portion of silt and clay fraction, at most $>30 \%$ (Table 1 ). High percentage of silt and clay was shown in all parent materials of landslide deposit, ranging from $19-61 \%$ and $11-73 \%$ respectively. On the other side, the percentage of sand seems to be very low, ranging from 6 - 38\% (Table 1). Good soil for crops is reflected by the ideal composition of particle size. In further, the soil which is textured with silt and clay will have optimum availability for crops, but in terms of nutrition, clay soil is better than dusty textured soil [11].

The high content of clay in the study area is mostly caused by pedogenic process of volcanic ash material that has being developed into soil. This had been proved by [33] stated that weathering of volcanic ash as finely comminuted igneous rock resulted in the formation of clay minerals. In further, it was explained that at this advanced stage of weathering in the tropics, imogolite and/ or allophane were matillage limitr weathering products under moderate rainfall condition; noncrystalline $\mathrm{Fe}$ - and Al-hydroxides were matillage limitr weathering products under the extremely high rainfall condition. Beside pedogenic process, there was also an alteration process in particular areas that could accelerate the weathering process of the parent materials, and then form secondary minerals quickly [24].

Those conditions, actually, become the main problem in cultivating the land in the study area. However, the existence of landslides, in another side, provides a positive impact on land because it can help to break up the solid soil structure due to pedoturbation during landslide occured. Even though the soil particle sizes in the study area were dominated by clay (See table 1), the movement process during landslides caused the soils to be mixed. Consequently, this process resulted in the structure and consistence of landslide deposit were fragmented (See table 1), and thus the landslide deposit was easy to be cultivated.

Bulk volume and bulk density have a close relationship with porosity [12]. Bulk volume also affects infiltration, root depth, availability of plant nutrients, and soil microorganism activity so that it can affect plant growth [29]. The bulk volume of landslide deposit has a range of $1.01-1.48 \mathrm{gr} / \mathrm{cm}^{3}$. Bulk volume of landslide deposit was usually lower than the nearby non-landslide soils [24]. Bulk volume is directly proportional to the dominant size of particles in the soil. The more clay percentage is, the lower the bulk volume 


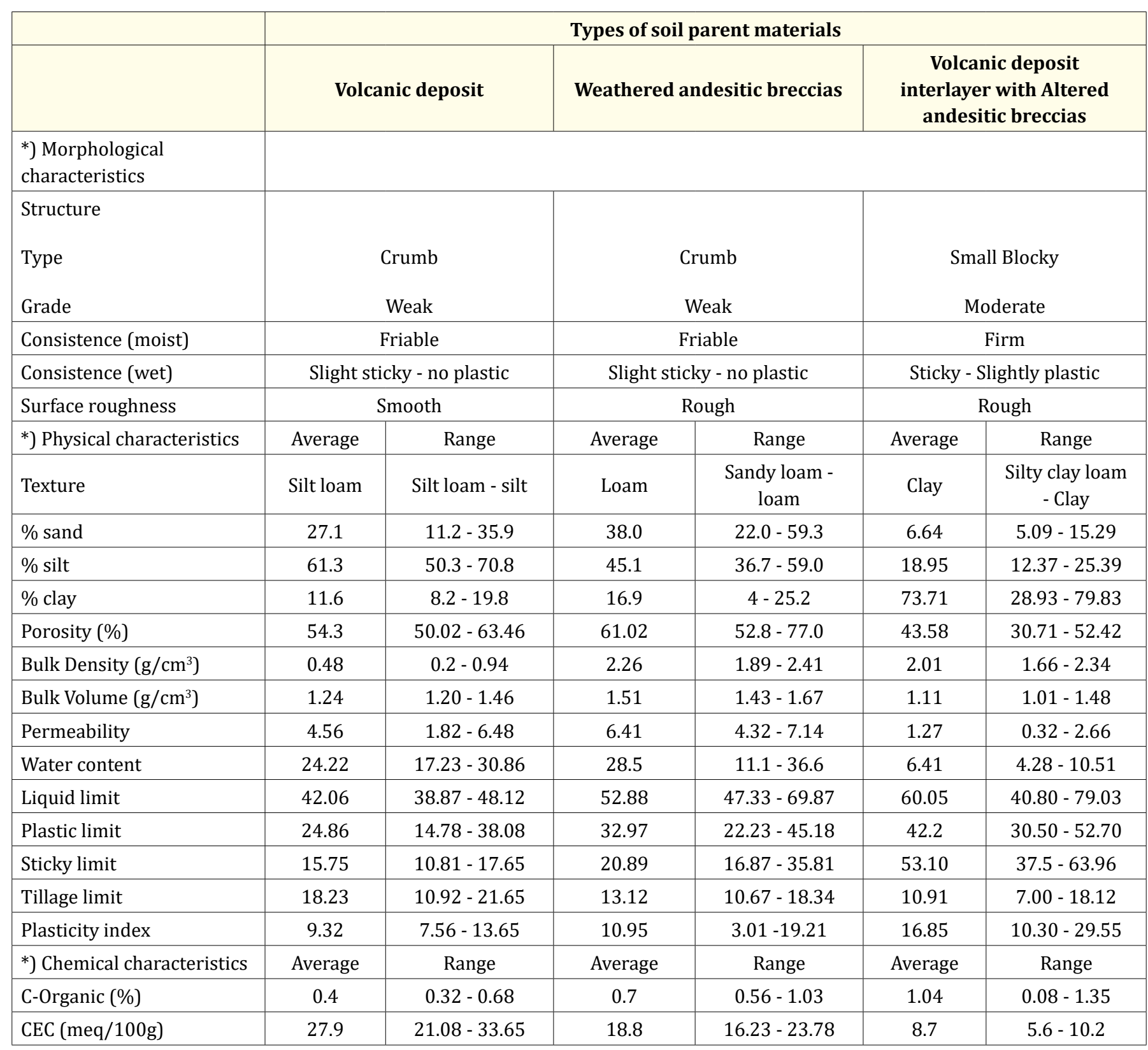

Tabel 1: Average of soil properties in landslide deposit areas.

will be. Soils that have a high clayey content have a large surface area so they tend to have a high interaction with water, and the clay fraction has a wider micropore space causing a high porosity density. According to the [29], soils that have a clay texture of more than $45 \%$ and a bulk volume of less than $1.1 \mathrm{~g} / \mathrm{cm}^{3}$ are good for root growth. Therefore, landslide deposit in the study area has a potential to support plant root growth.
Permeability in landslide deposit have a lower value than it in inactive landslides. Active landslides indicate that the soil conditions have been stirred so that the soil conditions are more friable. Permeability describes the stability of the structure [12]. This is supported by [7] which states that landslide deposits cause low soil permeability. The dominant permeability value in the study 
area varied from slightly slow to moderate which can indicate that the soil texture had a more dominant of fine fraction.

Tillage limit is a crucial property showing the ability of soil to be cultivated. Soil with low tillage limit is more difficult to be cultivated than soil with high tillage limit. The tillage limit of landslide deposit in the study area is categorized into medium to high level. Therefore, this result showed that the landslide deposit is able to be cultivated. The level of tillage limit of landslide deposit is significantly depended on sticky limit and plastic limit. It is because tillage limit was derived from magnitude of difference in water content at the plastic limit and sticky limit [31]. Sticky limit of landslide deposit in the study area showed a very high level. High percentage of clay in the study area become the main reason for this very high of sticky limit. Furthermore, plastic limit of landslide deposit was just in medium level. The combination of those consistence limit of landslide deposit resulted in medium to high level of tillage limit.

Plasticity index is one of soil consistence parameter that is also significantly affected by landslides. Plasticity index was usually significant in clayey soil since it may describe the elasticity of soils. The plasticity index of landslide deposit in the study area was categorized into high level. Therefore, it showed that the landslide deposit is also able to be cultivated. The level of plasticity index of landslide deposit is significantly depended on the limit of liquid and plastic. It is because plasticity index was derived from magnitude of difference in water content at the limit of liquid and plastic [31]. The liquid limit of landslide deposit in the study area showed high to very high level. Soil that has high liquid limit proves that the soil is able to hold the maximum amount of air. Furthermore, the plastic limit of landslide deposit was just in medium level. The combination of those consistence limit of landslide deposit resulted in high level of plasticity index.

C-Organic was significantly affected by landslides [5]. However, among the types of landslide deposit, there were no significant differences of C-Organic content. On average, C-Organic content ranged from 0.5 to $1.04 \%$ (Table 1). This C-Organic content was categorized into low to very low level. [24] revealed that COrganic of landslide deposit was often lower than that of nearby non-landslide soil. This result is consistent with several previous studies which found that in the rough topographic areas, landslides mobilized the carbon significantly [5]. It was also examined by [4] reveled that $\mathrm{C}$ content is often high in the smooth relief because $\mathrm{C}$ content in the rough relief may be diminished by enhanced erosion and deposition.

C-Organic is part of organic matter which has crucial role in providing soil nutrient. With the high content of organic matter will affect the pore space. The higher the organic matter in the soil, the more large soil pore space and the greater the soil porosity (Hartillage limitwigeno, 2003). Also, the higher the organic matter determine the level of soil fertility [1].

Cation Exchange Capacity (CEC) was also significantly affected by landslides. On average, CEC content ranged from 8.7 to 27.9 (meq/100g) (Table 1). CEC significantly decreased following landslides, furthermore, these decreases were greater with increasing degree of landslide deposition [7]. Similar to C-Organic, CEC content had lower content in the landslide deposit due to the movement resulted from landslide activities. A mixing process in landslide deposit might refined the clay structure, and thus decreases the CEC.
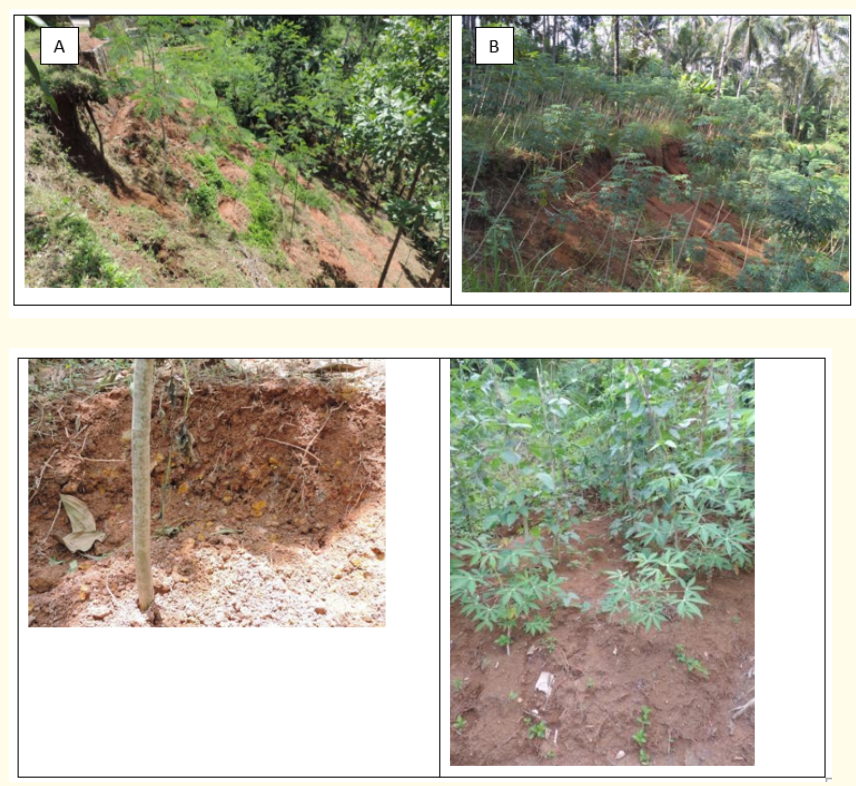

Figure 2: Landslide body used as an agricultural cultivation land in the study area: (a) landslide deposit which contains mixed of soil and saprolite planted by wood crops; (b) landslide deposit which contains mainly of soils planted by seasonal crops. 
Due to those characteristics of soil properties, landslide deposit in the study area seems to be suitable to be used as an alternative agricultural cultivation land. The important point were shown by tillage limit and plasticity index. The tillage limit and plasticity index of landslide deposit showed that the landslide deposit has a possibility to be cultivated. High content of clay, which is the main problem in the study area, can be solved due to landslide activity. The landslides, in fact, can change the soil structure which is mostly compact to be broken up. Consequently, the characteristics of landslide deposit was usually loose material and unwell-sorted grain sizes. It was shown by morphological characteristics of the landslide deposit which have crumb to small blocky soil structure under weak to moderate grade, and having mainly friable soil consistence (Table 1). Furthermore, it was supported by [24] stated that landslide deposit may act as a new soil parent material at landslide susceptible areas. This is because most of landslide deposit plays a role as the upper-most layer of soil and retards the underneath soil development.

Landslide deposit was a mixture of all materials in the form of soil, soil parent material, and rock. Based on its characteristics, landslide deposit in the study area were categorized into two types, i.e. landslide deposit which contains mainly of soil and landslide deposit which contains mixed of soil and saprolite. Therefore, landslide deposit in the study area was possible to be directly cultivated. However, both types of landslide deposit have low content of organic matter (See table 1). Consequently, under this condition, suitable types of crops should be considered. Landslide deposit that contains mainly of soil was suggested to be planted with seasonal crops i.e. cassava, long bean, curcuma, and sweet potato (Figure 2). It is because this type of landslide deposit is more friable, so it is better to be planted with plants that do not increase the soil load. However, landslide deposit contained by mixed of soil and saprolite were possible to be planted with wood crops i.e. teak wood and sengon (Figure 2). This is because this type of landslide deposit was not only contained by soils but also saprolite. Thus, this material has an ability to hold the plants stronger than the friable soil, also it was possible to be infiltrated by tap root plants.

\section{Conclusion}

Landslide deposit in Bogowonto watershed seems to be suitable to be used as an alternative agricultural cultivation land. Based on the soil consistency data, it strengthens that landslide deposit can be cultivated with plants even though this area has a high content of clay. However, land expansion in areas under intensive land degradation must be in accordance with the characteristics of particular land. In landslide deposited areas, suitable types of crops should be considered in order to use the particular soil as agricultural cultivation media. Landslide deposit contained mainly of soil was suggested to be planted with seasonal crops. Landslide deposit contained by mixed of soil and saprolite were possible to be planted with wood crops.

\section{Bibliography}

1. Afandi H and Novpriansyah H. "Karakteristik Sifat Fisik Tanah Pada Lahan Produksi Rendah Dan Tinggi Di Pt Great Giant Pineapple". Jurnal Agrotek Tropika 3.2 (2015): 278-282.

2. Aliyyah H L. Kajian Ketersediaan Air Untuk Tanaman Pada Lahan Bekas Longsor Di Sub Das Bompon, Kabupaten Magelang, Jawa Tengah, Skripsi, Fakutas Pertanian UGM, Yogyakarta (2020).

3. Arnold R W. "Concepts of Soils and Pedology". In L. Wilding, N. Smeck, and G. Hall (Eds.), Pedogenesis and Soil Taxonomy: I. Concept and Interactions. Elsevier Science Publishers, Amsterdam (1983).

4. Badia D., et al. "Influence of slope and parent rock on soil genesis and classification in semiarid mountainous environments". Geoderma (2013): 193-194, 13-21.

5. Błońska E., et al. "The Effect Of Landslide On Soil Organic Carbon Stock And Biochemical Properties Of Soil". Journal of Soils and Sediments 18 (2018): 2727-2737.

6. Bui LV., et al. "A Fuzzy Logic Slope-Form System For Predictive Soil Mapping Of a Landscape-Scale Area With Strong Relief Conditions". Catena 155 (2017): 135-146.

7. Cheng C., et al. "Landslide-Induced Changes Of Soil Physicochemical Properties In Xitou, Central Taiwan". Geoderma 265 (2016): 187-195.

8. Cork S., et al. "The Relationships Between Land Management Practices And Soil Condition And The Quality Of Ecosystem Services Delivered From Agricultural Land In Australia". Australian Government Department of Agriculture Fisheries and Forestry (2012). 
9. Erlanda EP., et al. "Kajian Sedimentasi Pada Sumber Air Baku Pdam Kota Pontianak". Jurnal Teknik Sipil 12.2 (2012): 151162.

10. Gui Jin., et al. "Land Use Suitability Assessment In Low-Slope Hilly Regions Under The Impact Of Urbanization In Yunnan, China”. Advances In Meteorology (2015): 9.

11. Hanafiah KA. Dasar-Dasar Ilmu tanah. ed. 1-cet.6.-Jakarta; Rajawali Press. Jakarta: Raja Grafindo Persada (2005).

12. Hardjowigeno S. Ilmu Tanah. Akademika Pressindo. Jakarta (2003).

13. He J., et al. "Identifying Vegetation Restoration Effectiveness And Driving Factors On Different Micro-Topographic Types Of Hilly Loess Plateau: From The Perspective Of Ecological Resilience". Journal of Environmental Management 289 (2021): 112562.

14. Istiqomah ZSR. Karakteristik Kesuburan Fisik Tanah Permukaan Di Longsorlahan Tidak Aktif Das Bompon Kabupaten Magelang, Jawa Tengah, Skripsi, Fakutas Geografi Ugm, Yogyakarta (2018).

15. Jiang L., et al. "The Impact Of Urban Expansion On Agricultural Land Use Intensity In China". Land Use Policy 35 (2013): 33-39.

16. Kartasapoetra G A G., et al. Teknologi Konservasi Tanah Dan Air. Rineka Cipta. Jakarta (1987).

17. Kuzman B and Prodanovic. Land Management In Modern Farm Production. International Scientific Conference Sustainable Agriculture And Rural Development In Terms Of The Republic Of Serbia Strategic Goals Realization Within The Danube Region: Development And Application Of Clean Technologies In Agriculture. Institute Of Agricultural Economics, Belgrade (2018): 292-308

18. Lihawa Fitryane. Daerah Aliran Sungai Alo Erosi, Sedimentasi Dan Longsoran. Deepublish, Yogyakarta (2017).

19. Liao T., et al. "Tradeoff Of Exploitation-Protection And Suitability Evaluation Of Low-Slope Hilly From The Perspective Of "Production-Living-Ecological" Optimization". Physics And Chemistry of The Earth, Parts A/B/C 120 (2020): 102943.
20. Meiarti R. "Analisis Pola Spasial Distribusi Longsor Untuk Penentuan Faktor Pengontrol Utama Longsorlahan Di Das Kodil Jawa Tengah". Skripsi, Fakutas Geografi Ugm, Yogyakarta (2013).

21. Niacşu L., et al. "Optimum Agricultural Land Use In The Hilly Area Of Eastern Romania. Case Study: Pereschiv Catchment". Carpathian Journal of Earth and Environmental Sciences 10.1 (2015): 183-192.

22. Partap. "Sustainable Land Management In Marginal Mountain Areas Of The Himalaya Region". Mountain Research and Development 19.3 (1999): 251-260.

23. Pulungan NA. Landslide risk management by means of proposed land use in Gintung Sub-Watershed, Purworejo Regency, Central Java Province, Indonesia. Master Thesis, Gadjah Mada University, Indonesia (2011).

24. Pulungan NA. Spatial Patterns Of Soil Characteristics And Soil Formation In The Transitional Landscape Zone, Central Part Of Bogowonto Catchment, Java, Indonesia. Dissertation. Innsbruck University. Austria (2016).

25. Ray P., et al. "Agricultural Land Use Planning: An Effective Means Of Enhancing Tribal Farmers' Income In Asom". Indian Farming 68.1 (2018): 88-90.

26. Reijntjes Coen. Haverkort, Bertus., Dan Waters-Bayer, Ann. Pertanian Masa Depan. Kanisius, Yogyakarta (1999).

27. Rosskopf C M., et al. "Assessing Spatial Variability And Erosion Susceptibility Of Soils In Hilly Agricultural Areas In Southern Italy". International Soil and Water Conservation Research 8.4 (2020): 354-362.

28. Satriawan Halus Dan Faudy Zahrul. Teknologi Konservasi Tanah Dan Air. Deepublish, Yogyakarta (2014).

29. Stirzaker RJ., et al. "Soil structures and plant growth: Impact of bulk density and biopores". Plant and Soil 185 (1996): 151162.

30. Tarolli P and Straffelini E. "Agriculture In Hilly And Mountainous Landscapes: Threats, Monitoring And Sustainable Management". Geography and Sustainability 1.1 (2020): 70-76. 
31. Tagar AA., et al. "Soil failure patterns and draft as influenced by consistency limits: An evaluation of the remolded soil cutting test". Soil and Tillage Research 137 (2014): 58-66.

32. Verheye. "Management Of Agricultural Land: Climatic And Water Aspects". In: W. H. Verheye (Ed.), Land Use, Land Cover And Soil Sciences, Oxford, Uk: Unesco-Eolss Publish (2006).

33. Wada K. "Minerals formed and mineral formation from volcanic ash by weathering". In: Y. Ogura (Guest Editor), Proceedings of An International Seminar on Laterite, October 14-17, 1985, Tokyo, Japan. Chem. Geol., 60 (1987): 17-28.

34. Zink JA. Geopedology: Elements Of Geomorphology For Soil And Geohazard Studies; Itc Special Lecture Notes Series. Faculty Of Geo-Information Science And Earth Observation Enschede, The Netherlands (2013).

35. Zhang Q., et al. "Dynamics And Driving Factors Of Agricultural Landscape In The Semiarid Hilly Area Of The Loess Plateau, China". Agriculture, Ecosystems and Environment 103.3 (2004): 535-543.

36. Zhang W., et al. "Nutrient Loss Is Sensitive To Land Cover Changes And Slope Gradients Of Agricultural Hillsides: Evidence From Four Contrasting Pond Systems In a Hilly Catchment". Agricultural Water Management 237 (2020): 106165.

Volume 5 Issue 9 September 2021

(C) All rights are reserved by Nur Ainun Harlin Jennie Pulungan. 